\title{
DIE EENHEID VAN WOORD EN GEES BY CALVYN MET BESONDERE VERWYSING NA DIE PREDIKING
}

Ds. C. F. C. Coetzee

\section{AKTUALITEIT}

Die stryd in die $16 \mathrm{e}$ eeu het uiteindelik saamgetrek in die vraag na cie verhouding tussen Woord en Gees. D'Assonville noem Calvyn se siening soos dit na vore kom in sy brief aan Sadoletus, tereg „een van die grootste momente in sy Teologiese insig, een van die grondstene van die hele Reformatoriese leer, een van die belang. rikste beginsels wat nooit mag verwaarloos word nie, waarsonder geen suiwer kerkbegrip ooit kan bekom word nie en waarsonder die prediking in die kerk gedoem is tot mislukking" ${ }^{2}$. Dit is ook vandag steeds die geval. In die vraagstukke waarmee ons te doen het, o.a. rondom die Skrif, die Persoon en werk van die Heilige Gees, die Kerk en die prediking, is die siening van die verhouding tussen Woord en Gees van die grootste belang. Daar moet in die huidige tyd opnuut gevra word, nie net na die feit van die verbinding tussen Woord en Gees nie, maar ook na die „hoe" van hierdie verbinding, die wyse waarop ons dit moet sien. In beide opsigte is die siening van Calvyn as teoloog van die Woord en teoloog van die Heilige Gees, steeds van rigtinggewende betekenis. As ons goed na Calvyn luister, bemerk ons die hartstog om binne die grense van die geskrewe Woord te bly. Hy wil nie swyg waar die Heilige Gees spreck nie, maar hy wil ook nie verder gaan as wat die Gees getuig nie ${ }^{2}$. En dit is ook ons roeping.

\section{DIE EENHEID VAN WOORD EN GEES}

Die eenheid en onafskeidelikheid van Woord en Gees is een van Calvyn se karakteristieke leerstukke ${ }^{3}$. Hy noem dit nie 'n dwaling nie, maar wel 'n raserny wanneer die band van Woord en Gees losgemaak word ${ }^{4}$. Die positie-beklemtoning van hierdie eenheid is in volkome ooreenstemming met die verkondiging van die Skrif. Holwerda verwys in hierdie verband na Eichrodt wat die aandag daarop gevestig het dat die uitsprake van die Skrif met betrekking tot die Woord die oor die Gees eenvoudig kruis ${ }^{5}$. Die twee reekse loop in die mate ewewydig, dat wat op die een plek oor die Woord gesê word, elders aan die Gees toegeskryf word.

\subsection{Rome en die Anabaptiste}

In sy stryd op twee fronte, nl. teen Rome aan die een kant en teen die Doperse rigting aan die ander kant, het Calvyn die besondere insig ontvang dat Rome en die Anabaptisme in dié opsig 'n gemeenskaplike vyand vorm, deurdat by albei die band tussen Woord en Gees losgemaak word. In sy antwoord aan Sadoletus stel hy dit soos volg: „Het voornaamste wapen waarmee zij beiden ons aanvallen is hetzelfde. Want als zij buitensporig op de Geest pochen, 
is hun bedoeling stellig het Woord van God te begraven, dan maken zij ruimte voor hun eigen drogredeneringen.... het is niet minder onredelijk om op de Geest te pochen zonder het Woord, dan dat het dwaas zou zijn het Woord op zichzelf naar voren te schuiven zonder de Geest" ".

Dit is nie Calvyn nie, maar wel Rome en die Dopers wat die kontinuiteit van die katolieke kerk verbreek en haar ware gestalte misvorm het, deur die Woord en die Gees van mekaar los te maak ?

Wat Rome betref, word die Gees losgemaak van die Woord deurdat $\mathrm{Hy}$ in die kerklike amp van die Pous vermaterialiseer word ${ }^{8}$. Hierteenoor vra Calvyn aan Sadelotus: „Maar watter plek het die Woord van God dan, daardie duidelikste kenmerk wat die Here Self by die aanwysing van Sy kerk so dikwels aanbeveel? Omdat $\mathrm{Hy}$ naamlik vooruitgesien het hoe gevaarlik dit sou wees om voortdurend oor die Gees los van die Woord te spreek, het Hy wel die versekering gegee dat die Kerk deur die Heilige Gees gelei word, maar sodat ons nie sou dink dat hierdie leiding vaag en onseker is nie, het Hy dit (die kerk) aan die Woord gebind 9." En in sy kommentaar op Joh. 16:14 stel hy Rome se standpunt soos volg: „Indien aan die Pous die Skrif voorgehou word sê hy dat mens nie daaraan moet bly hang nie omdat die Gees wat daarna gekom het, veel daaraan toegevoeg het en ons daardeur daarbo verhef het. Deur 'n vals beroep op die Gees is dus die wêreld betower om van die eenvoudige suiwerheid van Christus af te wyk. Want sodra jy die Gees van Christus losmaak, staan die deur oop vir allerlei dwaasheid en leuens."

Dieselfde bedrieglike weg bewandel die Dopers. Ook hulle beskou die Gees as 'n tweede openbaringsbron wat van die Woord losgemaak en op die innerlikheid van die selfstandige individu betrek word ${ }^{10}$. Van hulle sê Calvyn: „Die leer wat geskryf staan is vir hulle maar 'n letter. Daarom wil hulle 'n nuwe teologie maak wat uit openbaringe sou bestaan ${ }^{11}$." Hierdie sogenaamde openbaringe word deur Calvyn beskou as waansinnige ingewinge van die duiwel omdat nie alleen die diens van mense nie maar die Skrif self verag word om die Gees te verkry ${ }^{12}$.

Teenoor sowel Rome as die Doperse rigting handhaaf Calvyn die eenheid en onafskeidelikheid van Woord en Gees. Die werk van die Heilige Gees is niks anders nie as om die ryk van Christus te versterk en alles wat Hom deur die Vader gegee is te bevestig. Die leer van die Heilige Gees dien nie daartoe om ons van Christus af te trek nie maar veel liewer om vir ons daardie Woord te bevestig, waardeur ons beveel word om na Hom te luister ${ }^{13}$. Die amp van die Gees is nie om nuwe openbaringe te gee nie maar om dit wat in die Evangelie geleer word, in die siele te laat posvat ${ }^{14}$. Die handhawing van die eenheid van Woord en Gees impliseer nie 'n onreg teenoor die Gees nie, maar die Gees word aan die ander kant wel beledig wanneer aan Hom aparte openbaringe toegeskryf word en sy eie werk, die Heilige Skrif sodoende as ongenoegsaam beskou word ${ }^{15}$. Die buitengewone openbaringe het hulle tyd gehad voor die afsluiting van die Kanon ${ }^{18}$. 


\subsection{Luther en Zwingli}

Voordat ons oorgaan tot 'n volledige uiteensetting van die standpunt van Calvyn is dit nodig om kortliks te let op die standpunte van Luther en Zwingli, veral met die oog op die siening van die wyse waarop die band tussen Woord en Gees bestaan en funksioneer. Vir Luther is alles geleë in die objektiewe Woord wat beteken dat die Gees in die Woord beslote lê en dat die Woord dus ex opere operato werk. Na die verskyning in 1621 van die geskrif van Hermann Rahtmann waarin hy geleer het dat die Woord alleen geen $\mathrm{krag}$ het om die mens te bekeer nie, tensy die Heilige Gees met sy genade daarby kom, het die Lutherse teoloë uit reaksie teen hom die egte Lutherse leer ontwikkel, dat die Woord van God die krag van die Heilige Gees tot bekering in homself besit, dat die krag deur Goddelike beskikking daarin gelê is en so onafskeidelik daarmee verbonde is ${ }^{17}$. "God works through His word, which is like a vehicle or a tool whereby we learn to know Him in our heart" ${ }^{18}$. Ons kom later weer terug op die standpunt van Luther en volstaan hier met die kritiek van Walters ${ }^{10}$ : „It can be admitted that the emphasis on the objectivity of the Word is a healthy one, but his further emphasis on the almost indissoluble union between the word of preaching and the Word of the Spirit tends towards being a mechanical opus operatum."

Zwingli het uit reaksie teen die standpunt van Luther die Woord gereduseer tot niks meer as 'n teken of simbool of getuienis aangaande Christus nie en dit gevolglik nie beskou as openbaring of genademiddel in die regte sin van die woord nie. Zwingli maak dan ook ' $n$ onderskeiding tussen die Verbum Dei externum, die uitwendige woord wat gespreek word as 'n heenwysing na Christus, en die Verbum Dei internum, die effektiewe werking van die Heilige Gees in die hart. Hierdie twee werkinge kan volgens Zwingli gelyktydig plaasvind, maar ook apart. Die Heilige Gees kan dus direk in die hart werk sonder die Woord, 'n standpunt wat in wese weer neerkom op ' $n$ verbreking van die band tussen Woord en Gees ${ }^{20}$.

Walters wys daarop dat Calvyn teenoor die uiterstes van Luther en Zwingli 'n tussenstandpunt inneem. „He holds strongly to the fact that the Holy Spirit is present in the Word and also to the equally certain fact of the witness of the Spirit in the believer's heart. His intention is to strike the balance between those, on the one hand, who make extravagant claims for the preached word and those on the other hand who aver 'that it is a criminal transfer to mortal man of what properly belongs to the Holy Spirit, to suppose that ministers and teachers penetrate the heart and mind (Inst. IV, 1, 6)" ${ }^{21}$.

\subsection{Die Testimonium Spiritus Sancti Internum}

Dit bring ons by die leer aangaande die Testimonium Spiritus Sancti wat deur Calvyn op meesterlike wyse uitgebou is. Hieronder verstaan ons die getuienis van die Heilige Gees by en deur die Woord om die mens tot die geloof te bring, en dan nie net die geloof in die Woord as die Woord van God nie, maar in die eerste plek die saligmakende geloof, die persoonlike toe-eiening van Jesus 
Christus, die vleesgeworde Woord, as jou Verlosser en Saligmaker. Tot hierdie geloof kan geen mens kom sonder die werking (testimonium) van die Heilige Gees nie. Calvyn self stel dit soos volg in sy Institusie 22: Soos ons geensins tot Christus kan nader tensy ons deur God se Gees getrek is nie, so word ons, wanneer ons getrek word, met ons verstand en gemoed uitgevoer bo ons eie insig. Want die deur-Hom-verligte siel kry as 't ware 'n nuwe skerpsinnigheid, waarmee dit die hemelse verborgenheid gadeslaan, deur die glans waarvan dit tevore verbind is. En wanneer die verstand van die mens so deur die lig van die Heilige Gees bestraal is, begin dit eers waarlik te smaak dit wat behoort tot die Koninkryk van God terwyl dit tevore geheel en al dwaas en onverstandig was om dit te proe. Calvyn verwys hier na die ontmoeting tussen Christus en die Emmausgangers en ook na Joh. $16: 13$ en sê van laasgenoemde teks: So moes ook aan die apostels, wat deur sy Goddelike mond onderwys is, tog die Gees van waarheid gestuur word, om in hulle verstand in te druppel dieselfde leer wat hulle met hulle ore verneem het. Die Woord van God is wel soos 'n son wat toestraal almal aan wie dit verkondig word; maar dit is sonder enige vrug te midde van blindes. En ons is almal van nature blind in hierdie opsig; daarom kan dit in ons hart nie deurdring nie, tensy die inwendige Leermeester, die Gees, deur sy verligting die toegang berei.

Die testimonium Spiritus Sancti is 'n werking van die Heilige Gees wat in ons geoefen word (intus), ons verlig (illuminare) en onderwys (docere), ons oortuig dat die Heilige Skrif die Woord van God is (persuadere) en dienaangaande vastheid en oortuiging by ons bring (obsignare, sigillum; certitutidem consequi), ons onder die invloed van die Skrifmajesteit bring, sodat ons gewillig en welbewus daarvoor buig (serio afficere). Dit toon ook aan waar hierdie werking geskied (in die hart) en wat dit uitwerk (verligting, beseëling, vaste oortuiging), en hoe dit werk ${ }^{23}$. Die werk van die Heilige Gees is allereers om ons harte te ontsluit vir dit wat God ons skenk in sy Woord. Hy verleen aan ons die geskiktheid vir die hemelse wysheid. Hy open die oë van ons gees. Hy sou dus nie ongepas nie, die sleutel genoem kan word en sy verligting die vermoë van ons gees om te sien ${ }^{24}$.

Ons het dus hier met 'n werking van die Gees te doen wat noodsaaklik is nie vanweë 'n ongenoegsaamheid of onvolkomenheid van die Woord nie, maar vanweë die mens se natuurlike blindheid as gevolg van die sonde.

Calvyn behandel hierdie getuienis in sy Institusie in die eerste plek met betrekking tot die geloof dat die Woord God se Woord is ${ }^{25}$. Die oortuiging aangaande die Goddellike outeurskap van die Skrif is alleen moontlik deur die getuienis van die Heilige Gees. „There is only one valid way for us to grasp the importance of Scriptural truth and this is by knowing that God Himself is the Author of Scripture. This knowledge comes not through the ordinary mental steps which one would use to determine the author of a book but by the special testimony of the Holy Spirit. In the inner man the 
Holy Spirit moves and secretly witnesses to God's Authorship of the Bible" ${ }^{28}$.

Hierdie getuienis moet egter nie so verstaan word, as sou dit die grond vorm vir ons geloof in die Goddelike gesag en inspirasie van die Skrif nie. Hierdie grond lê in die Skrif self en dit werk as God se Woord op ons in. Dog dit is die testimonium Spiritus Sancti, die werking van die Heilige Gees wat ons innerlik geskik maak om hierdie inwerking van die Heilige Skrif qua God se Woord te ondergaan en dit as sodanig te erken en wat ons mettertyd tot die erkenning bring ${ }^{27}$. Dat die Skrif God se Woord is, is dus geleë in die outopistie van die Skrif self. Maar sekerheid by ons kry die Skrif as God se Woord alleen deur die getuienis van die Heilige Gees Netsoos God alleen van Homself kan getuig in sy Woord, so vind sy Woord alleen geloof in die hart van 'n mens nadat dit beseël is deur die inwendige getuienis van die Heilige Gees ${ }^{28}$.

As ons nou die Institusie en die Kommentare van Calvyn saam bestudeer word dit verder duidelik dat die testimonium Spiritus Sancti nie net betrekking het op die gesag van die Skrif nie, maar ook op die inhoud. Krusche praat in hierdie verband van die Skrifsekerheid sowel as die Heilsekerheid ${ }^{29}$. Dit moet ook nie as twee afsonderlike getuienisse gesien word nie, maar is een getuienis. Anders gestel: Die Heilige Gees werk deur die Woord die geloof in Christus en bring daarmee saam die gelowige ook tot die erkenning van die Skrif as God se Woord. Dit is dus alleen vir 'n gelowige moontlik om die Skrif as God se Woord te erken.

Hierdie getuienis van die Heilige Gees impliseer dus ook geen aparte bewussynsinhoud buite dit wat ons in die Skrif geopenbaar is nie. Trouens, die Gees moet in sy werkinge in ons getoets word aan die Skrif. In die Skrif het Hy Homself geteken en aan daardie Skrifbeeld moet Hy in sy werkinge in die mens herken, en na daardie beeld in die Skrif moet $\mathrm{Hy}$ in die innerlike werkinge beoordeel en erken word ${ }^{30}$.

Ray kom tot die volgende slotsom, waarby ons kan aansluit: „As to Calvin's position in regard to the witness of the Holy Spirit, we must conclude by saying that in his eyes the Spirit and the Word are always related in their work. It is the function of the Holy Spirit to witness to the One Word, preparing the way in our minds and hearts for the reception of the Word and binding us to Christ Who is the Word. Without the gifts of the Word and Spirit man cannot find his way to God ${ }^{31}$.

In die beklemtoning van die Goddelike inspirasie van die Skrif in die nouste verband met die heilsverkondiging en in die handhawing van die balans tussen die uitwendige faktor, nl. die Woord wat verkondig of gelees word, en die inwendige faktor, nl. die Heilige Gees wat immanent in die mens werk by en deur die Woord, word ons bewaar vir die dwaling van dooie ortodoksie aan die een kant en geesdrywery aan die ander kant.

Die beeld van die saad van die Woord wat by die mens soos in goeie aarde val as gevolg van die werking van die Heilige Gees, druk die verhouding van Woord en Gees by Calvyn ook treffend uit. 
Krusche gee in hierdie verband aandag aan die gebruik van die woord begeleiding as uitdrukking van wat Calvyn presies bedoel ${ }^{32}$.

Hierby moet dit egter beklemtoon word dat die werksaamheid van die Gees gelyktydig met die Woord, of die prediking van die Woord geskied (non ante, nec post sed simul) en dat ons aan hierdie semul moet dink as 'n „Goddelike gelyktydigheid" ${ }^{33}$. Ons kan dus hoogstens daarvan praat dat die immanente werking van die Heilige Gees logies, maar nie temporeel nie, aan die Woord voorafgaan ${ }^{34}$.

Samevattend kan ons sê dat die verhouding tussen Woord en Gees die beste uitgedruk word, deur te sê dat die Heilige Gees in, deur en by of met die Woord werk. Sodoende word die absolute eenheid en onafskeidelikheid van Woord en Gees onverswak gehandhaaf terwyl die onderskeid tussen die Woord en die Gees ook die nodige erkenning ontvang.

\section{DIE PREDIKING}

Wat hierbo gesê is in verband met die verhouding Woord en Gees, geld in dieselfde mate vir die prediking. Trouens, talle van die uitsprake waarna ons verwys het, het juis betrekking op die prediking. Ter wille van duidelikheid voeg ons nog enkele gedagtes van Calvyn in verband met die prediking by, ook met die oog daarop om die verskil tussen hom en veral Luther duideliker na vore te bring.

Calvyn kon die belangrikheid van die prediking nie genoeg beklemtoon nie ${ }^{35}$. Nie net die inspirasie van die Skrif nie maar ook die interpretasie van die Woord is die werk van die Heilige Gees ${ }^{36}$. Die Heilige Gees werk in die eerste plek en veral in die gewone geordende diens van die Woord waarin die Doctrina salutis ontvou en toegeëien word ${ }^{37}$. Daarom is die prediking die Woord van God wat van Godsweë tot die mens kom, deur die Heilige Gees gespreek word en daarom ook altyd sy werk doen. Die Woord van God is altyd en oral 'n krag van God, die swaard van die Gees ${ }^{38}$. Dit is so in drievoudige sin, $\mathrm{nl}$. eerstens omdat dit die interpretasie en verklaring van die Bybel is, die Woord van God, tweedens omdat die prediker deur die Heilige Gees geroep word en derdens in die sin dat dit openbaring is ${ }^{39}$. Na die predikers wat die Woord van God interpreteer moet geluister word asof dit God self is wat spreek ${ }^{40}$. Paulus daag selfs die engele uit om sy prediking te weerlê ${ }^{41}$. Nie net die ontstaan van die geloof nie, maar ook die heiligmaking van die gelowige is die werk van die Heilige Gees deur die prediking van die Woord ${ }^{42}$.

Wat die gesag van die prediking betref as die wyse waarop die Heilige Gees die geloof werk, is daar nie verskil tussen Luther en Calvyn nie. Die verskil moet gesoek word in die wyse waarop die band tussen Woord en Gees bestaan en funksioneer. Luther sluit die Gees as 't ware op in die Woord. Die Gees werk deur die Woord (per verbum) op 'n outomatiese en magiese wyse. Calvyn beskou hierdie standpunt van Luther as 'n heerskappy van die mens oor die Gees ${ }^{43}$. Hy beklemtoon ook die eenheid van die Woord en 
Gees maar gebruik die terminologie dat die Heilige Gees in 'n sekere sin in die Woord ingesluit is (quodammodo inclusa) ${ }^{44}$. Hier kom duidelik Calvyn se versigtigheid na vore, dat hy die eenheid van Woord en Gees ten volle handhaaf, maar aan die ander kant die werking van die Heilige Gees nie reduseer tot 'n magiese krag nie.

Die standpunt van Luther bied dan ook geen aanneemlike verklaring vir die werklikheid dat die Woord nie altyd die geloof werk nie, maar dikwels ook die verharding. Om die verskillende uitkoms van die Woord te verklaar moet Luther uiteindelik die toevlug neem tot die vrye wil van die mens. Hierteenoor handhaaf Calvyn die eenheid maar ook die onderskeid tussen Woord en Gees. Die Heilige Gees is nie 'n onbewuste krag nie, maar 'n Persoon, wat altyd by die Woord is, dit altyd dra en werksaam laat wees, alhoewel nie altyd werksaam laat wees op dieselfde wyse nie. Hy werk altyd deur die Woord dog nie altyd op dieselfde wyse nie. Hy besig na die onnaspeurlike welbehae van God die Woord tot bekering of tot verharding. Die Woord is die Woord van God. Maar sodat die saad van die Woord goeie vrugte dra, moet dit in 'n goed toebereide aarde val. Die akker moet vir die ontvangs van die saad gereed gemaak word. Hierdie immanente werksaamheid van die Heilige Gees is ' $n$ andere, subjektiewe werksaamheid, nie 'n werksaamheid per verbum nie, maar cum verbo.

Calvyn stel sy standpunt baie duidelik in sy kommentaar op Hand. 16:14: ..., ,netsoos die prediking alleen niks anders is as 'n dooie letter nie, so moet ons wederkerig op ons hoede wees dat geen valse inbeelding of ' $n$ skyn van verborge verligting ons afvoer van die Woord, waar die geloof van afhang en waarop dit rus nie. Want daar is baie mense wat, om die gawe van die Gees te vermserder, hulleself inbeeld dat hulle sulke verligte persone is dat hulle die uitwendige Woord nie meer nodig het nie. Maar die Skrif duld nie dat Woord en Gees op 'n dergelike wyse van mekaar geskei word nie, terwyl die Skrif steeds die diens van mense met die verborge werking van die Heilige Gees verbind. Indien die verstand van Lydia nie verlig is nie, sou die prediking van Paulus 'n dooie letter gewees het; maar God het haar nie slegs die verligting van die Heilige Gees gegee nie maar ook eerbied vir sy Woord; sodat die stem van mense wat anders in die lug verlore sou gaan, in haar deur Goddelike lig-bestraalde verstand binnegedring het. Die fanatieke mense wat onder voorwendsel van die gawe van die Heilige Gees die uitwendige leer verag, dwaal dus. Want ons moet die balans hou wat Lukas hier aangee, dat ons uit die gehoor van die Woord alleen geen nut het nie sonder die genade van die Gees; en dat aan ons die Gees geskenk word, nie wat ons leer om die Woord te verag nie, maar veeleer wat die geloof in die Woord in ons verstand indruppel en in ons harte inskryf."

Die predikers van die Woord sou sonder resultaat roep, indien Christus, die inwendige Leermeester nie self deur sy Heilige Gees hulle tot Hom trek wat aan Hom deur die Vader gegee is nie ${ }^{45}$.

\section{SLOTOPMERKINGS}

Soos in die tyd van die Reformasie woed die stryd ook vandag 
op verskillende fronte. Hier kan veral gedink word aan die rasionalistiese bevraagtekening van die gesag van die Skrif ${ }^{46}$ aan die een kant en die verskynsels soos die neo-pentakostalisme aan die ander kant. Beide hierdie dwalinge kom neer op 'n ontkenning van die band tussen Woord en Gees.

In samehang met bogenoemde verskynsels word die huidige tyd gekenmerk deur 'n bevraagtekening van die posisie van die Kerk in die wêreld en word dit steeds meer as die roeping van die kerk gesien om hom aktief te bemoei met die sosio-politieke vraagstukke, aktief deel te neem aan die stryd van terroristiese magte, ensomeer. Dit lei op sy beurt, of tot Skrifverdraaiing in die prediking of tot 'n devaluasie van die prediking. Die antwoord op al hierdie vraagstukke is geleë in die beklemtoning van die eenheid van Woord en Gees. Sodoende sal die Kerk hom steeds bepaal by sy primêre roeping, die suiwere verkondiging van die Woord, en sal die arbeid van die teoloog in die beoefening van die wetenskap en die besluite van die Kerk op sy vergaderings bo alles gekenmerk word deur onvoorwaardelike gehoorsaamheid aan die Woord.

Lesing gehou voor die GTV Potchefstroom, 7 Augustus 1978.

1 D'ASSONVILLE, V. E. Calvyn verdedig sy stad; sy antwoord aan kardinaal Sadoletus in 1539. Potchefstroom, Pro Rege, 1974. p. 10.

2 HET DOGMA der Kerk, onder red. van G. C. Berkouwer en G. Toornvliet. Met medewerking van $\mathrm{A}$. de Bondt, G. Brillenburg Wurth e.a. Groningen, Haan, 1949. p. 50.

3 BALKE, W. Calvijn en de Doperse radikalen. Amsterdam, Bolland, 1973. p. 142 .

4 Institusie I, IX, 1.

5 HOLWERDA, B. Populair-wetenschappelijke bijdragen. Goes, Oosterbaan en Le Cointre, 1962. p. 14.

6 BRIEF aan Sadoletus, aangehaal deur BALKE, a.w. p. 141. Vgl. ook D'ASSONVILLE, a.w. p. 11.

7 BALKE, a.w. p. 143.

8 ROSSOUW, H. W. Klaarheid en interpretasie; enkele probleemhistoriese gesigspunte in verband met die leer van die duidelikheid van die Heilige Skrif. Amsterdam, Campen, 1963. p. 299.

9 BRIEF aan Sadoletus, aangehaal deur D'ASSONVILLE, a.w. p. 10.

10 ROSSOUW, a.w. p. 2999.

11 Kommentaar op Joh. $16: 14$.

12 BALKE, a.w. p. 249.

13. Kommentaar op Joh. $16: 14$.

14 GREY DANUS, S. Karakter van het Testimonium Spiritus Sancti volgens Calvijn. In Gereformeerd theologisch tijdschrift, jg. 14, aflewering 11, Maart 1914. p. 537.

15 KRUSCHE, Werner. Das Wirken des Heiligen Geistes nach Calvin. Gottingen, Vandenhoeck \& Ruprecht, 1957, p. 215.

16 Vir 'n volledige uiteensetting uit die Institusie en kommentare van Calvyn, vgl. o.a. WALTERS, Gwyn, The doctrine of the Holy Spirit in John Calvin. 1949. p. $278 \mathrm{ev.}$ 
17. BAVINCK, H. Gereformeerde dogmatiek. 2e herz. en verm. dr. Kampen, Kok 1906 . 1911. Dl IV, p. 501.

18 Luther se TISCHREDEN, Weimarer Ausgabe, III, p. 674, aangehaal deur WALTERS, a.w. p. 230.

19 WALTERS, a.w. p. 230.

20 Ibid, p. 230, 231.

21 Ibid. p. 231.

22 Institusie III, II, 34. Vgl. ook: FORSTMAN, H. Jackson, Word and Spirit; Calvin's doctrine of Biblical authority. Stanford, Calif., Stanford Univ. Press, 1962. p. 76.

23 GREIJDANUS, a.w. p. 531.

24 Ibid, p. 534, ev.

25 Institusie I, VIII; vgl. ook GREIJDANUS, a.w. p. 522.

26 RAY, Richard Archibald. The inner witness of the Holy Spirit to the Word, with special reference to contemporary protestant theology in the United States. 1964. p. 62.

27 GREIJDANUS, a.w. p. 540. Vgl. hier ook KRUSCHE, a.w. p. 212 ev.: „Das Testimonium internum begründet nicht die Gewiszheit von der Göttlichkeit der Schrift, sondern erzeugt sie. ....Wäre das testimonium spiritus sancti Grund unserer Gewiszheit vom götlichen Ursprung der Schrift, so muszte es verstanden sein als eine wahrnehmbare, in einem materialen Bewusztseinsinhalt bestehende Erfahrung. Dann wăre hier von einem Erfahrungsbeweis zu sprechen: das Zeugnis des Heiligen Geistes, das ein Moment meines Bewusztseins bildet, wäre dle Instanz, die meine Gewiszheit, es in der Schrift mit den ipsissima verba Del zu tun zu haben, begründete, auf die ich mich also zu berüfen hätte."

28 BAVINCK, a.w. dl. I,p. 626.

29 KRUSCHE, a.m. p. 217.

30 GREIJDANUS, a.w. p. 544.

31 Institusie IV, VIII, 13; Kommentaar op Rom. 11 : 34; vgl. ook RAY, a.w. p. 72.

32 KRUSCHE, a.w. p. 227 ev.

33 Ibid., p. 230.

34 Ibid.

35 Ibid., p. 222: „Das verbum praedicatum ist fur Calvin das eigentliche Gnadenmittel."

36 Institusie IV, I, 5; vgl. ook FORSTMAN, a.w. p. 77 ev.; WALTERS, a.w. p. 74.

37 BALKE, a.w. p. 250.

38 Institusie IV, XIV, 11; vgl. ook BAVINCK, a.w., dl. IV, p. 501; KRUSCHE a.w. 226 ev.

39 WALTERS, a.w. pp. 231 tot 236.

40 Institusie IV, I, 5.

41 Gal. $1: 8$; vgl. Calvyn se kommentaar.

42 Kommentaar op Joh. $15: 3$.

43 WALTERS, a.w. p. 235.

44 KRUSCHE, a.w. p. 231; vgl. ook BALKE, a.w. p. 342.

45 Institusie III, I, 4.

46 Wat die Suid-Afrikaanse teologie betref, dink ons hier veral aan die gedagtes wat in die jongste tyd o.a. deur W. S. VORSTER uitgespreek is. Vgl. sy: 'n Ou Boek in 'n nuwe wêreld; gedagtes rondom die interpretasie van die Nuwe Testament. Pretoria, Universiteit van Suid-Afrika (c 1977). 